\title{
Are incidence rates of schizophrenia decreasing?
}

\author{
POVL MUNK-JØRGENSEN
}

«In epidemiology you will always find something going up or something going down». A Swiss psychologist teased me with this statement during the AEP symposium on psychiatric epidemiology and social psychiatry in Zürich in the spring of 1992. She precisely hit the target as what contemporary schizophrenia epidemiology is concerned.

During the past few years we have seen several reports from various parts of the Western World documenting a clear decrease in first admission rates of schizophrenia, or in first contact schizophrenia rates. The results are reported from Australia (Parker et al., 1985), New Zealand (Joyce, 1987), England and Wales (Der et al., 1990; de Alarcon et al., 1990; Harrison et al., 1991), Scotland (Dickson \& Kendell, 1986; Eagles \& Whalley, 1985; Eagles et al., 1988) and Denmark (Munk-Jorgensen, 1986; MunkJørgensen \& Jørgensen, 1986; Munk-Jørgensen, 1987; Munk-Jørgensen \& Mortensen, 1992). Investigations from Croatia (Folnegovic et al., 1990) and London (Castle et al., 1991) contradict the above mentioned studies. However, looking into the two latter there are some specific explanations so all in all it can be concluded that first admission rates or first contact rates of schizophrenia are decreasing.

Now, from this decrease in administrative rates it would be tempting to conclude that a decrease in incidence has occurred in the population. However, one can never deduce from administrative data and use the results on the population.

Admission rates are only to a certain degree dependent on incidence. Several threshold factors as availability of services, parapsychiatric service e.g.

Indirizzo per la corrispondenza: Dr. P. Munk-Jørgensen, Institute of Psychiatric Demography, Psychiatric Hospital in Aarhus, DK-2840 Risskov, Denmark.

Fax $(+45)$ 86-175.977. number and educational level of GPs, geographical distance to services, insurance and payment, detection in primary care, psychological factors, pretreatment morbidity, etc. (Goldberg \& Huxley, 1980) are of importance.

What might cause a decrease in first admission rates or first contact rates?

Change in service organization has been mentioned (Eagles et al., 1988; Munk-Jørgensen \& Mortensen, 1992). This has both a positive and a negative impact. The positive one points to an increased competence in outpatient clinics and daypatient settings. Some of the studies mentioned correct for this (Eagles et al., 1988, de Alarcon et al., 1990; Castle et al., 1991; Harrison et al., 1991). Therefore, one cannot conclude that new cases are treated in other services than inpatient settings. In the same way one can argue against the hypothesis that the GPs and private practising psychiatrists should have taken over treatment of new cases (Munk-Jørgensen \& Mortensen, 1992).

Changing diagnostic patterns could also be a possible explanation. Introduction of new treatment possibilites might change the diagnostic habits (Baldessarini, 1970; Hare, 1974). Mors (1988) showed that e.g. borderline diagnoses have become more common also in Denmark. The diagnosis is widely given to patients diagnosed schizophrenia later in the course of illness. To a certain extent Munk Jørgensen \& Mortensen (1992) corrected for these changes in diagnostic practice in their Danish studies, and de Alarcon (1990) did from Oxford. Anyhow, the two studies showed a decrease in first admission and first contact rates, respectively.

Migration is another possible explanation. Against this, one can argue that migration normally will remove healthy individuals from an area and leave the sick and disordered, while the contrary is rare. 
Drift of schizophrenics, particularly men, towards larger cities is also a possibility, as Eagles et al. (1988) mention. In Denmark where imigration is close to zero the decrease in first admission rates is highly significant (Munk-Jørgensen \& Mortensen, 1992). In this connection it is worth mentioning Youssef et al's work (1991) from a rural area in Ireland. The authors found unchanged rates for men over a period while the rates for women were decreasing. The conclusions drawn from this work are, however, limited by a modest number of probands.

It might have been more difficult to pass the threshold to psychiatric treatment during the past two decades? This question is difficult to answer. Schizophrenia is a rar disease - with a prevalence at approximately $0,5 \%$ - so even very few persons not entering the treatment system will have a great impact on first admission rates. Such patients will be very difficult, not to say almost impossible, to identify outside the treatment system.

We might get some hints where to look for the unidentified schizophrenic individuals by analyzing the outcome of patients already diagnosed schizophrenia.

Firstly, the attention should be drawn to the fact that a decrease in first admission rates is seen in exactly the same period as the deinstitutionalization ideology blows over the Western World. In Denmark there is a parallel decrease in number of available beds and a decrease in, for instance, schizophrenia first admission rates. As a matter of fact, we see a parallel decrease in most illness groups in psychiatry (Munk-Jørgensen \& Mortensen, 1992).

Exemplified by the situation in Denmark (MunkJorgensen \& Mortensen, 1992) it has been documented that standard mortality rates among newly diagnosed schizophrenics have increased over the past fifteen years, $100 \%$ for both males and females within the year following their first schizophrenia diagnosis. Suicides form the majority. In Denmark we also witness a growing number of schizophrenics in shelters for homeless. A number equivalent to what is seen in the UK and the USA. Also the number of psychoses among criminals is increasing, so whereever we look for marginalized persons we meet an increasing number of schizophrenics. As it is possible to identify patients diagnosed schizophrenia in such places we might hypothesize that also persons not yet diagnosed are present.

Of course, one cannot deny a genuine decrease in the population but the political and administrative causes mentioned above should be eliminated before one accepts the decreasing incidence hypothesis.
Changing diagnostic patterns should also be further investigated. However, a hypothesis of a genuine decrease still cannot be rejected, but it might be interesting to see this in the light of findings of correlation between influenza exposure during gestation and schizophrenia in adult life (Kendell \& Kemp, 1989; Barr et al., 1990; Sham et al., 1992) and correlation between prenatal complications and later developing schizophrenia (McNiel et al., 1992). As these theories are not the topic here, I will end by suggesting that the «missing» schizophrenics also might be suffering from morbus politicus or morbus administratus.

\section{REFERENCES}

Baldessarini R. J. (1970). Frequency of diagnoses of schizophrenia versus affecive disorders from 1944 to 1968 . American Journal of Psychiatry 127, 759-763.

Barr C. E., Mednick S. A. \& Munk-Jorgensen P. (1990). Exposure to influenza epidemics during gestation and adult schizophrenia. Archives of General Psychiatry 47, 869-874.

Castle D., Wessely S., Der G. \& Murray R. M. (1991). The incidence of operationally defined schizophrenia in Camberwell, 1965-84. British Journal of Psychiatry 159, 790-794.

de Alarcon J., Seagrott V. \& Goldacre M. (1990). Trends in schizophrenia. The Lancet 335, 852-853.

Der G., Gupta S. \& Murray R. M. (1990). Is schizophrenia disappearing? The Lancet 335, 513-516.

Dickson W. E. \& Kendell R. E. (1986). Does maintenance lithium therapy prevent recurrences of mania under ordinary clinical conditions? Psychological Medicine 16, 521-530.

Eagles J. M. \& Whalley L. J. (1985). Decline in the diagnosis of schizophrenia among first admissions to Scottish mental hospitals from 1969-78. British Journal of Psychiatry 146, 151-154.

Eagles J. M., Hunter D. \& McCance C. (1988). Decline in the diagnosis of schizophrenia among first contacts with psychiatric services in North-East Scotland, 1969-1984. British Journal of Psychiatry 152, 793-798.

Folnegovic Z., Folnegovic-Smalc V. \& Kulcar Z. (1990). The incidence of schizophrenia in Croatia. British Journal of Psychiatry $156,363-365$.

Goldberg D. \& Huxley P. (1980). Mental Illness in the Community. The Pathway to Psychiatric Care. Tavistock: London.

Hare E. H. (1974). The changing content of psychiatric illness. Journal of Psychosomatic Research 18, 283-289.

Harrison G., Cooper J. E. \& Gancarczyk R. (1991). Changes in the administrative incidence of schizophrenia. British Journal of Psychiatry 159, 811-816.

Joyce P. R. (1987). Changing trends in first admissions and readmissions for mania and schizophrenia in New Zealand, 1974 to 1984. Australian and New Zealand Journal of Psychiatry $21,82-86$.

Kendell R. E. \& Kemp I. W. (1989). Maternal influenza in the etiology of schizophrenia. Archives of General Psychiatry 46, 878-882. 
McNiel T. F., Torrey F., Sjöström K., Cantor-Graae E., Bowler A., Taylor E. \& Higgins N. (1992). Histories of obstetric complications and neonatal abnormalities in monozygotic twins concordant and discordant for schizophrenia. Schizophrenia Research 6, 106.

Mors O. (1988). Increasing incidence of borderline states in Denmark from 1970-1985. Acta Psychiatrica Scandinavica 77, 575-583.

Munk-Jorgensen P. (1986). Decreasing first-admission rates of schizophrenia among males in Denmark from 1970 to 1984. Changing diagnostic patterns? Acta Psychiatrica Scandinavica 73, 645-650.

Munk-Jorgensen P. (1987). Why has the incidence of schizophrenia in Danish psychiatric institutions decreased since 1970? Acta Psychiatrica Scandinavica 75, 62-68.
Munk-Jorgensen P. \& Jorgensen P. (1986). Decreasing rates of first-admission diagnoses of schizophrenia among females in Denmark 1970-84. Acta Psychiatrica Scandinavica 74, 379-383.

Munk-Jorgensen P. \& Mortensen P. B. (1992). Incidence and other aspects of the epidemiology of schizophrenia in Denmark, 1971-87. British Journal of Psychiatry 161, 489-495.

Parker G., O'Donnel M. \& Walter S. (1985). Changes in the diagnoses of the funtional psychoses associated with the introduction of lithium. British Journal of Psychiatry 146, 377-382.

Sham P. C., O'Callaghan E., Takey N., Murray G. K., Hare E. H. \& Murray R. M. (1992). Schizophrenia following pre-natal exposure to influenza epidemics between 1939 and 1960. British Journal of Psychiatry 160, 461-466.

Youssef H. A., Kinsella A. \& Waddington J. L. (1991). Evidence for geographical variations in the prevalence of schizophrenia in rural Ireland. Archives of General Psychiatry 48, 254-258. 
Cesario Bellantuono - Matteo Balestrieri - Mirella Ruggeri

Michele Tansella

\section{DISTURBI PSICHICI NELLA MEDICINA GENERALE}

192 pagine. Lire 28.000

\section{Ringraziamenti}

\section{Introduzione}

La relazione medico-paziente nella medicina generale

I percorsi assistenziali dei pazienti con disturbi psichici: dalla popolazione alla medicina generale, ai servizi psichiatrici

Il passaggio attraverso il primo filtro: l'uso dei servizi sanitari da parte di persone con disturbi psichici e l'illness behaviour

Il passaggio attraverso il secondo filtro: il riconoscimento dei pazienti con disturbi psichici da parte del medico di medicina generale

La gestione e il trattamento dei disturbi psichici nella medicina generale

\section{Il paziente con disturbi d'ansia}

Che cos'è l'ansia?

Come riconoscere il paziente ansioso

Come gestire il paziente ansioso

La richiesta di un intervento specialistico

Il trattamento farmacologico dell'ansia

\section{Il paziente con disturbi depressivi}

Che cos'è la depressione?

Come riconoscere il paziente depresso

Come gestire il paziente depresso

La richiesta di un intervento specialistico

Il trattamento farmacologico della depressione

Il paziente con disturbi psicotici

Che cos'è la psicosi?

Come riconoscere il paziente psicotico

Come gestire il paziente psicotico

Il trattamento farmacologico dei disturbi psicotici

Conclusioni

Appendice 1. Indice degli psicofarmaci per classe terapeutica: principi attivi e preparati del commercio

Appendice 2. Indice degli psicofarmaci, in ordine alfabetico per nome commerciale di ciascun prodotto

Bibliografia

\section{Pensiero Scientifico Editore}

via Bradano 3/c - 00199 Roma

Tel. (06) 86207158/59/68/69 